\title{
Genetic diversity of Plum pox virus in Ukraine
}

\author{
O. V. Kutsenko, I. G. Budzanivska, O. V. Shevchenko \\ Educational and Scientific Center "Institute of Biology and Medicine", Taras Shevchenko National University of Kyiv \\ 64/13, Volodymyrska Str., Kyiv, Ukraine, 01601 \\ stahsenia16@ukr.net
}

\begin{abstract}
Aim. Establishing the genetic diversity of Plum pox virus (PPV) in Ukraine. Methods. Double antibody sandwich enzyme-linked immunosorbent assay (DAS-ELISA), polymerase chain reaction with reverse transcription (RT-PCR), DNA sequencing and phylogenetic analysis. Results. The samples with visual symptoms of virus infection were collected from different regions of Ukraine and diagnosed using DAS-ELISA. The amplicons of the coat protein (CP) gene were obtained using RT-PCR and sequenced. The obtained viral cDNAs were analyzed using phylogenetic methods to elucidate the genetic diversity of PPV in different regions of Ukraine. The phylogenetic relationships between Ukrainian isolates were studied and compared to PPV isolates from neighboring countries. Conclusions. The PPV strains M and D circulate in Ukraine. For the first time, PPV was found in the Kharkiv region. The PPV isolates circulating in Ukraine are similar to the isolates from Germany, Turkey, Hungary, and Canada. The results can be used to predict the spread of the virus in different Ukrainian regions and in neighboring countries and to establish its origin and predict the development of possible epidemics.
\end{abstract}

Keyword s: Plum pox virus, coat protein gene, phylogenetic analysis, sequencing, genetic diversity, Ukraine

\section{Introduction}

Plum pox virus (PPV) is a quarantine object and causative agent of severe disease of stone fruit trees known as sharka. PPV is widespread in almost all regions of Ukraine and is a serious threat to horticulture. The purpose of our research was to establish the genetic diversity of PPV in Ukraine using molecular methods.
Plum pox virus is known over hundred years and initially was discovered in Bulgaria in 1915 [1]. The disease caused by PPV was first described in Ukraine in 1966 and since then it has been spreading all over the country [2]. There are nine strains of PPV, the D and $\mathrm{M}$ strains are the most common [3-6]. All PPV strains differ in the transmission effi-

(C) 2019 O. V. Kutsenko et al.; Published by the Institute of Molecular Biology and Genetics, NAS of Ukraine on behalf of Biopolymers and Cell. This is an Open Access article distributed under the terms of the Creative Commons Attribution License (http://creativecommons.org/licenses/by/4.0/), which permits unrestricted reuse, distribution, and reproduction in any medium, provided the original work is properly cited 
ciency/mechanisms, the degree of pathogenicity and the range of host plants. Establishing the nucleotide sequence and molecular composition is a key aspect of the research aimed at studying the spread of viruses in different territories. The best way to control the spread and transmission of PPV is to create virusresistant plants. Genetic modification of the Prunus genus is currently poorly understood, but several approaches have already been developed to create resistant plants (such as genetic modification or engineering). In such a way, PPV infection on plums can be controlled or even completely eliminated. Such genetically modified organisms do not cause harm to human health. Experimental genetically modified plums carrying the coat protein gene of PPV showed high resistance to PPV infection [7]. In future, these approaches may form a base for selecting plants highly resistant to PPV. Nowadays, however, the main method for controlling sharka disease lies in the complete removal of infected plants, which leads to significant economic losses.

The rate of spread of the virus in the orchards depends on the distance between healthy trees and a source of infection (a diseased tree), when the efficiency of PPV transmission depends on the sensitivity of plant culture and density of aphid population [8]. Under natural conditions, this virus is extremely efficiently transmitted by a number of aphids in a non-persistent, non-circulating manner, and it was proved to be extremely difficult to control the vectors [9]. Transmission of the virus from country to country occurs mainly through planting material (cuttings and buds) [10].
According to the literature, Winona [11, 12], Marcus, and Dideron [13, 14] PPV strains were earlier detected in Ukraine. In general, previous characterization of some PPV isolates circulating in Ukraine showed their high homology regardless of the region or host plant [15]. This work is aimed at comparative description and phylogenetic analysis of PPV isolates found in different parts of Ukraine based on the sequences of coat protein gene for evaluating their epidemiological potential.

\section{Material and Methods}

The sampling of symptomatic stone fruits was conducted at private orchards and farms in Kyiv, Cherkasy, Odessa, Kharkiv, IvanoFrankivsk, and Vinnytsia regions during the growing seasons of 2016-2019. [The] Plants (plum, apricot, peach, cherry plum, cherry, and sweet cherry) with PPV-like symptoms were collected. The collected samples were first tested for PPV infection by direct double-antibody sandwich enzyme-linked immunosorbent assay (DAS-ELISA) [16], as described by Clark and Adams (1977) [17], using PPVspecific polyclonal antibodies (Loewe, Germany). Briefly, plant leaves were ground to a powder with mortar and pestle in $0.1 \mathrm{M}$ phosphate buffered saline (PBS), pH 7.4, $1: 3(\mathrm{~m} / \mathrm{v})$. Plant debris was removed by centrifugation at $5.000 \mathrm{~g}$ for $20 \mathrm{~min}$ at $+4^{\circ} \mathrm{C}$. The supernatant was used for ELISA. DAS-ELISA was performed according to the manufacturer's recommendations. Absorbance values at $405 \mathrm{~nm}$ were measured using a Thermo Labsystems Opsys MR microplate reader (USA).

Total RNA from naturally infected PPVpositive plant samples was isolated using 
RNeasy Plant Mini kit (Qiagen, UK). The two-step reverse transcription reaction (RTPCR) was accomplished using two specific primers complementary for the part of coat protein gene of PPV producing the amplicon with expected size of 243 bp. For RT-PCRbased virus detection [18] we used the primers proposed by Wetzel et al. (1991): P1 (5'-ACC GAG ACC ACT ACA CTC CC-3'), P2 (5'CAG ACT ACA GCC TCG CCA GA-3') [19]. Identification of different PPV strains is only possible if different primer pairs are used [8].

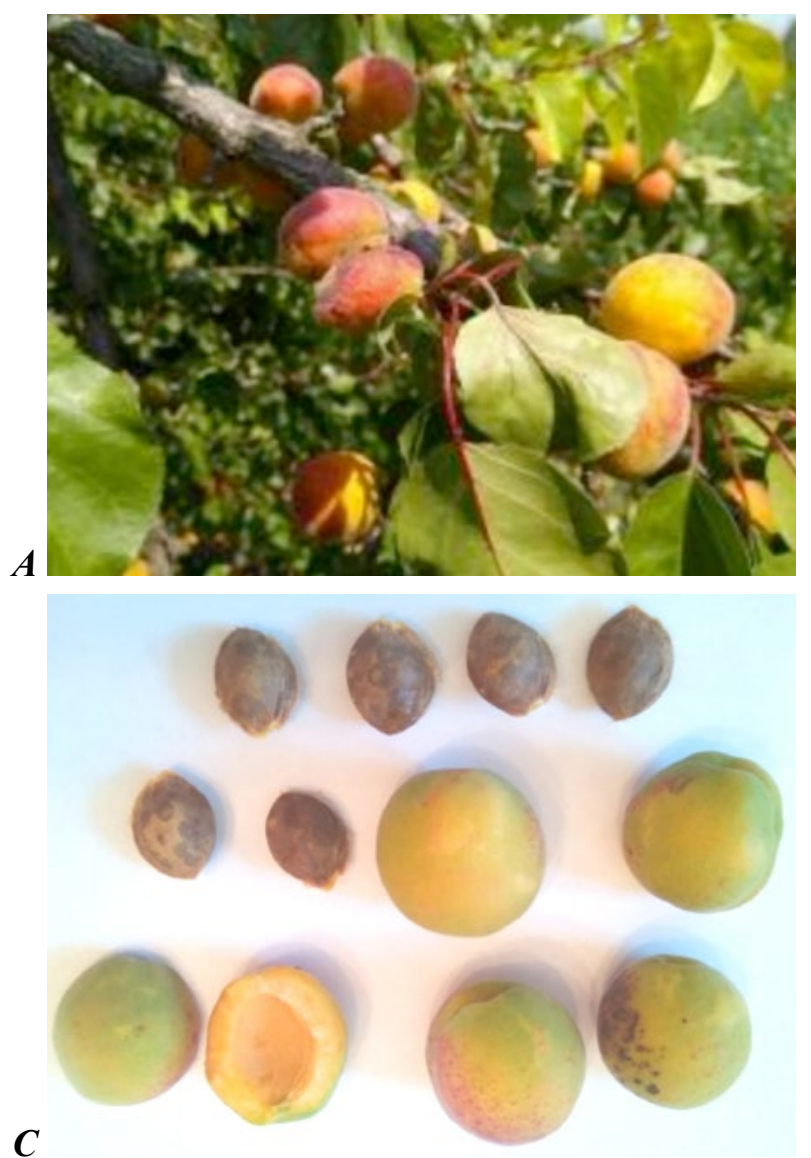

With this in mind, we used the primer sets to discriminate M, D, C, and Recs of PPV. For detection of PPV-D and PPV-M strains, we used the primers described by Olmos et al. (1997): P1 (5'-ACC GAG ACC ACT ACA CTC CC-3'), PD (5'-CTT CAA CGA CAC CCG TAC GG-3'), PM (5'-CTT CAA CAA CGC CTG TGC GT -3') [20]. For PPV-Rec strain detection, the mD5 and mM3 Recspecific primers were used as proposed by Šubr et al. (2004): mD5 (5'-TAT GTC ACA TAA AGG CGT TCT C-3'), mM3 (5'-CAT
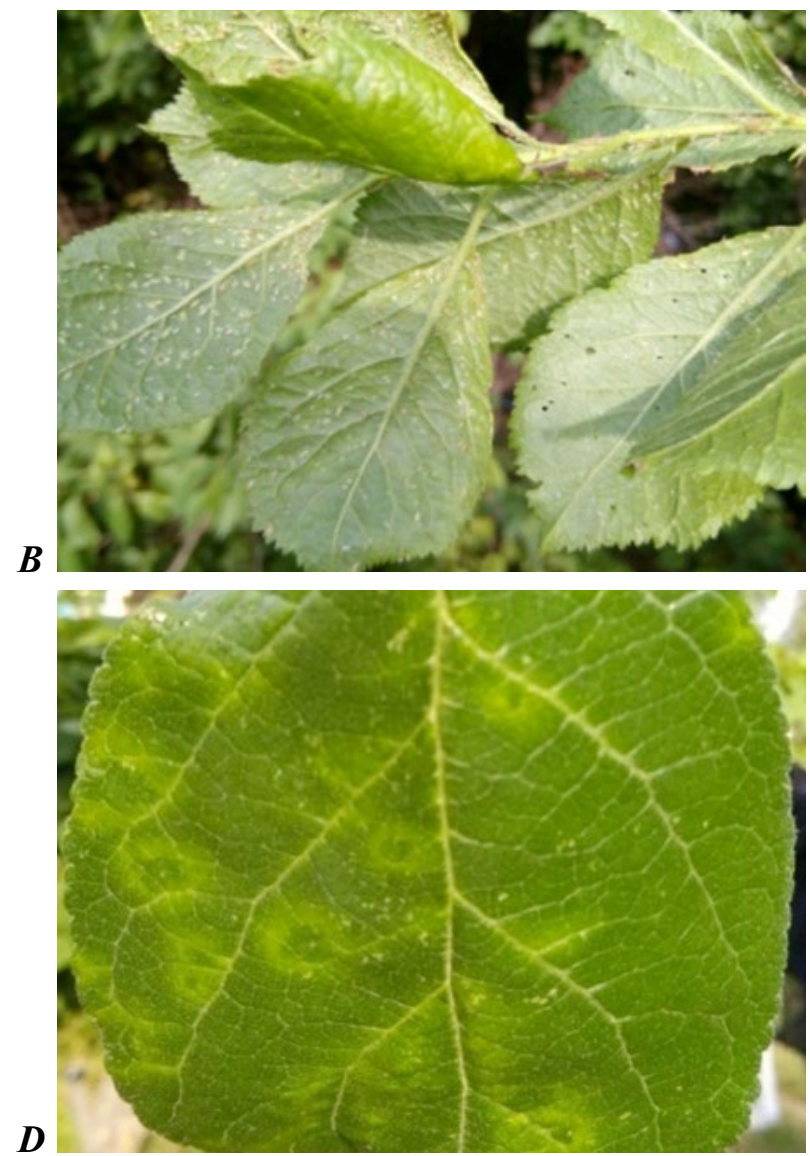

Fig. 1. Symptoms caused by PPV: $A$ - ringspots and blotches on apricot fruits, $B$ - leaf deformation on plum and plant damage due to aphid infestation, $C$ - ringspots and small necrotic lesions on apricot fruits (ringspot also seen on stones), $D$ - ringspots and vein clearing on plum leaves. 
TTC CAT AAA CTC CAA AAG AC-3') [21]. Finally, for detection of PPV-C strain the following specific primers were used: Soc2 (1) (5'-TCC-ACC-ATT-CCC-AAA-TCT-G-3'), and Soc2 (2) (5'-TAC-ATC-TCG-ATC-CTTCCT-C-3') [22].

Total RNA extraction and PCR amplification were assessed by electrophoresis in a $1.5 \%$ agarose gel in TBE buffer ( $89 \mathrm{mM}$ TRIS borate and 2 mM EDTA, $\mathrm{pH} 8.3$ ) stained with ethidium bromide. The amplification products were purified using MinElute Gel Extraction Kit (Qiagen, UK). The purified amplicons were sequenced using Applied Biosystems 3730x1 DNA Analyzer with Big Dye terminators, version 3.1 (Applied Biosystems, USA).

The aligned cDNA sequences of studied Ukrainian PPV isolates were compared with the nucleotide sequences of selected PPV strains and isolates publicly available from the GenBank database. The phylogenetic analysis was conducted using MEGA 7 software. The

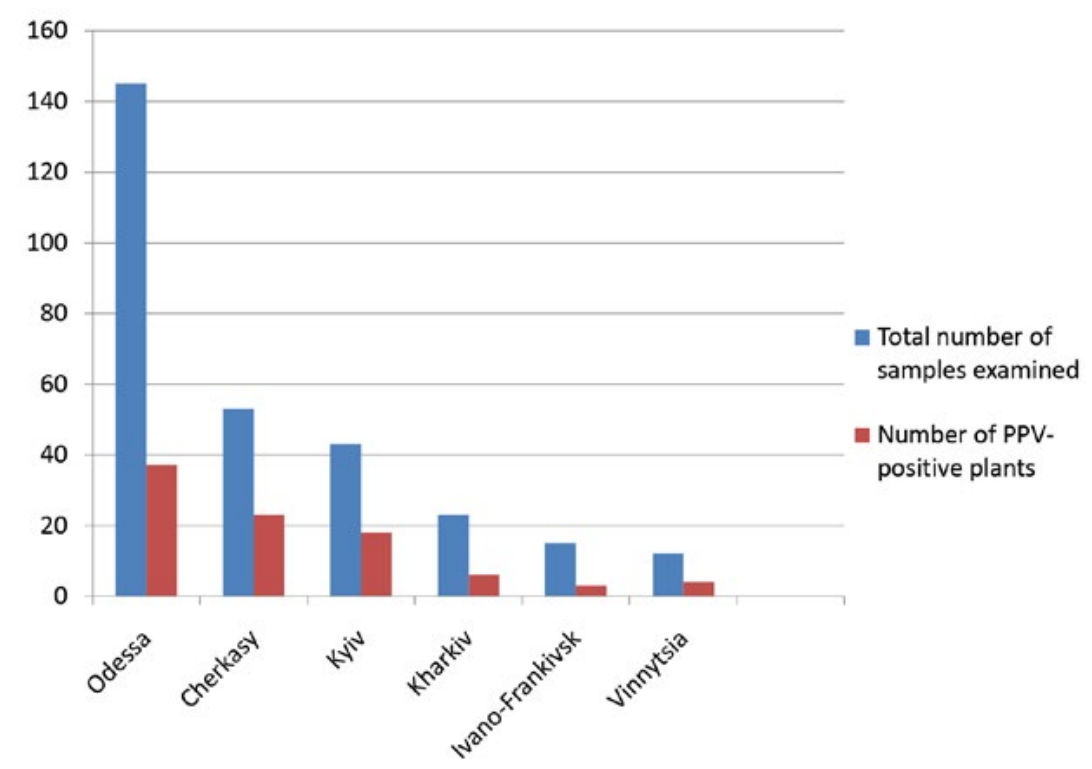

phylogenetic trees were constructed using the Neighbor-Joining (NJ) method.

\section{Results and Discussion}

The plant samples were collected during 20162019 years from different regions of Ukraine. The samples of plum, apricot, peach, cherry plum, cherry, and sweet cherry with symptoms of chlorotic spots/rings, deformation of leaves, small spots/pits and/or brown/reddish necrotic lesions on fruits, were collected (Fig. 1).

In total, about 300 samples were tested for PPV. Most of the samples were collected from the Kyiv, Cherkasy and Odessa regions, whereas the Kharkiv, Ivano-Frankivsk, and Vinnytsia regions were less represented.

PPV has been detected by DAS-ELISA in a modest part (31\%) of symptomatic plant samples in all regions (Fig.2) and in every host tested except the sweet cherry. The relative number of PPV-positive plants was similar in
Fig. 2. Serological detection of PPV in screened regions of Ukraine 
Table 1. PPV detection and strain discrimination by RT-PCR

\begin{tabular}{l|l|c|l|l}
\hline \multicolumn{1}{c|}{ Region } & \multicolumn{1}{c|}{ Host plants } & Strain(s) & \multicolumn{1}{c}{ Symptoms } & \multicolumn{1}{c}{ Year(s) } \\
\hline Kyiv & $\begin{array}{l}\text { Plum, apricot, } \\
\text { peach }\end{array}$ & D, M & $\begin{array}{l}\text { fruit deformation, leaf deformation, light green } \\
\text { mosaic, ringspots and small necrotic lesions }\end{array}$ & $2016-2019$ \\
\hline Cherkasy & Plum, peach & D & fruit deformation, leaf deformation, light green mosaic & $2016-2019$ \\
\hline Odessa & $\begin{array}{l}\text { Apricot, peach, } \\
\text { plum, cherry }\end{array}$ & D, M & $\begin{array}{l}\text { fruit deformation, leaf deformation, ringspots and } \\
\text { small necrotic lesions }\end{array}$ & $2016-2019$ \\
\hline Kharkiv & Plum & D & fruit deformation, ringspots and small necrotic lesions. & $2018-2019$ \\
\hline Ivano-Frankivsk & Plum, cherry & D, M & fruit deformation, leaf deformation, light green mosaic & $2017-2019$ \\
\hline Vinnytsia & Plum, apricot & D & $\begin{array}{l}\text { fruit deformation, leaf deformation, light green } \\
\text { mosaic, ringspots and small necrotic lesions }\end{array}$ & $2017-2019$ \\
\hline
\end{tabular}

the regions of the country. For the first time, PPV was found in the Kharkiv region.

Unexpectedly low number of PPV-positive samples in ELISA can be explained by a lower sensitivity of DAS-ELISA as compared to conventional PCR diagnostics.

All samples shown as PPV-positive in DASELISA were further tested using RT-PCR. The advantages of this diagnostic technique are high sensitivity and ability to discriminate between different strains of the virus. Molecular detection of PPV confirmed that the $\mathrm{D}$ strain was found in most of the host plants (plum, apricot and peach) and was the predominant strain of plum pox virus in all regions. In the Cherkasy, Kharkiv and Vinnytsia regions only the D strain of PPV was found. In contrast, the $\mathrm{M}$ strain was less common and was only found in apricot and peach plants (but not in plum or cherry plants) (Table 1). In contrast, PPV-Rec, PPV-C strains were not found in this study.

In total, the D strain was found in $73 \%$ of PPV-positive samples, whereas the M strain only in $27 \%$. Approximately $9 \%$ of samples were infected with both strains.

Partial nucleotide sequences of the $C P$ gene of seven Ukrainian isolates of PPV were de- termined and deposited in the GenBank: OdpeachDKd (Accession Number MK209071), ChplumMSt (Accession Number MK209072), OdpeachDKs (Accession Number MK209073), OdplumDSt (Accession Number MK209074), KapricotDKs (Accession Number MK209075), KpeachDOk (Accession Number MK209076), and OdpeachDSt (Accession Number MK209077).

These nucleotide sequences of Ukrainian isolates of PPV together with the sequences of other PPV strains available from the GenBank database and originating from different countries were used when constructing the phylogenetic tree (Fig.3). Partial nucleotide sequence of the $C P$ gene of potato virus $\mathrm{Y}$ was used as the out group.

Our results show a high ( $99 \%$ ) level of identity of the coat protein gene sequences of Ukrainian isolates of PPV regardless of their sampling site or the host plant, with clear segregation on the $\mathrm{D}$ strain and $\mathrm{M}$ strain isolates (Fig.3, Table 2). This finding may be indicative of either small number of historical events of virus introduction into the country or, alternatively, intense exchange/circulation of virus genetic material maintaining its homogeneity. 


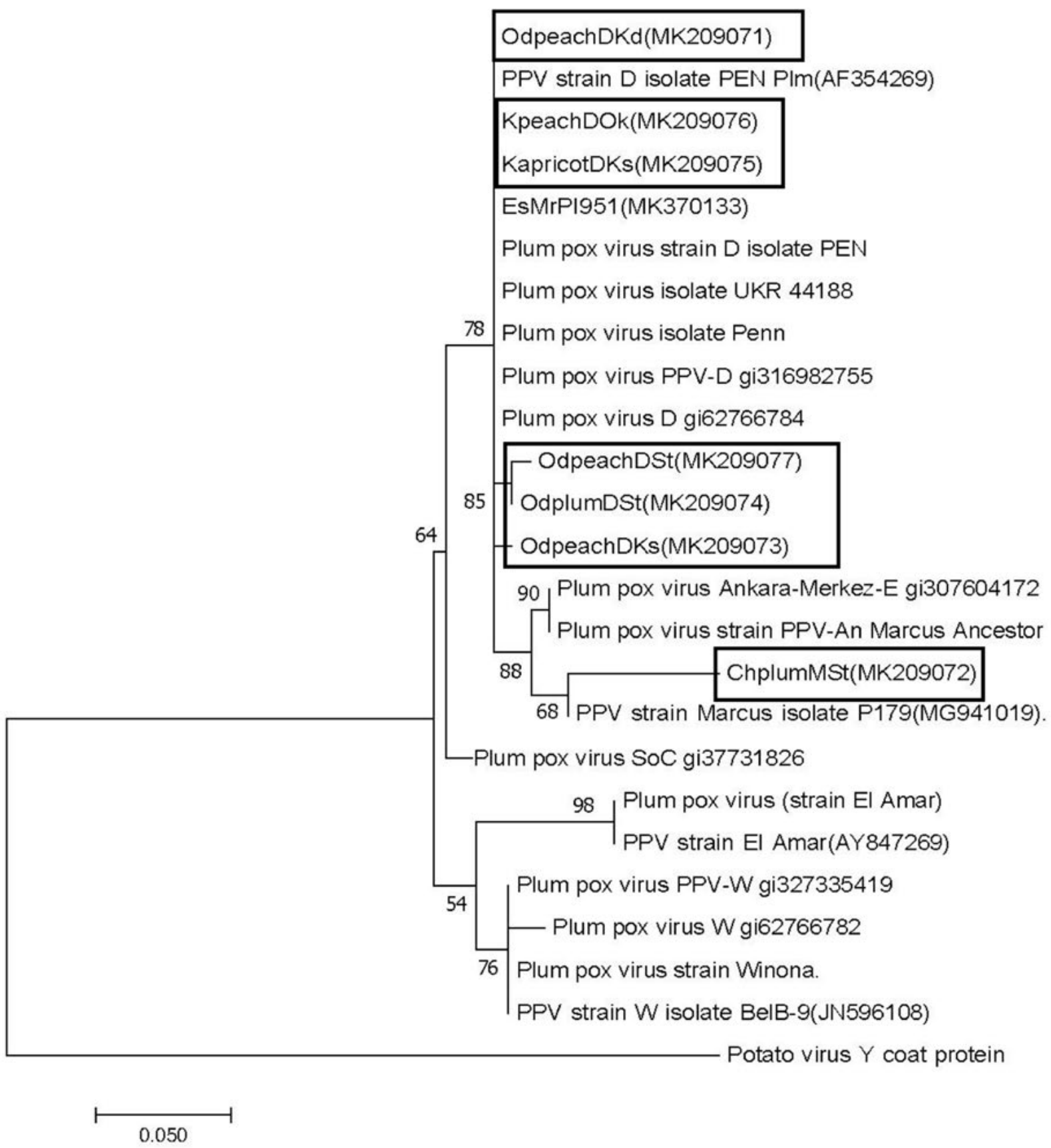

Fig. 3. Neighbor-Joining tree showing phylogenetic relationships among previously known strains/isolates of PPV and seven Ukrainian isolates based on their partial nucleotide sequences of the coat protein gene. Hasegawa-KishinoYano model + Gamma distribution $(\mathrm{HKY}+\mathrm{G})$. Bootstrap values are shown next to the nodes. Ukrainian isolates are shown in squares 
O. V. Kutsenko, I. G. Budzanivska, O. V. Shevchenko

Table 2.Identity of Ukrainian PPV isolates by partial sequences of their $C P$ gene, \%

\begin{tabular}{l|c|c|c|c|c|c|c}
\hline \multicolumn{1}{c|}{ Isolates } & $\begin{array}{c}\text { OdpeachDKd } \\
\text { (MK209071) }\end{array}$ & $\begin{array}{c}\text { ChplumMSt } \\
\text { (MK209072) }\end{array}$ & $\begin{array}{c}\text { OdpeachDKs } \\
\text { (MK209073) }\end{array}$ & $\begin{array}{c}\text { OdplumDSt } \\
\text { (MK209074) }\end{array}$ & $\begin{array}{c}\text { KapricotDKs } \\
\text { (MK209075) }\end{array}$ & $\begin{array}{c}\text { KpeachDOk } \\
\text { (MK209076) }\end{array}$ & $\begin{array}{c}\text { OdpeachDSt } \\
\text { (MK209077) }\end{array}$ \\
\hline $\begin{array}{l}\text { OdpeachDKd } \\
\text { (MK209071) }\end{array}$ & - & 91 & 99.3 & 97 & 100 & 100 & 98 \\
\hline $\begin{array}{l}\text { ChplumMSt } \\
\text { (MK209072) }\end{array}$ & 91 & - & 91 & 93 & 90.9 & 91 & 92 \\
\hline $\begin{array}{l}\text { OdpeachDKs } \\
\text { (MK209073) }\end{array}$ & 99.3 & 91 & - & 98 & 98 & 99.2 & 99 \\
\hline $\begin{array}{l}\text { OdplumDSt } \\
\text { (MK209074) }\end{array}$ & 97 & 93 & 98 & - & 99.2 & 98 & 99 \\
\hline $\begin{array}{l}\text { KapricotDKs } \\
\text { (MK209075) }\end{array}$ & 100 & 90.9 & 98 & 99.2 & - & 100 & 98 \\
\hline $\begin{array}{l}\text { KpeachDOk } \\
\text { (MK209076) }\end{array}$ & 100 & 91 & 99.2 & 98 & 100 & - & 97.3 \\
\hline $\begin{array}{l}\text { OdpeachDSt } \\
\text { (MK209077) }\end{array}$ & 98 & 92 & 99 & 99 & 98 & 97.3 & - \\
\hline
\end{tabular}

Ukrainian PPV isolate ChplumMSt (Accession number MK209072) belonged to the M strain of PPV and expectedly was less homologous to the other isolates as these were attributed to the D strain of the virus (Fig.3, Table 2). The remaining six PPV isolates belonging to the $\mathrm{D}$ strain were highly similar to each other (97-100\%) despite being collected in different years and from various hosts and regions. On the basis of the $C P$ gene, which is commonly used for deciphering PPV phylogeny, we were unable to show any significant differences between Ukrainian PPV isolates of the D strain Fig.3, Table 2).

Subsequent evaluation of evolutionary links of Ukrainian PPV isolates with those already published in the GenBank (Table 3) showed high level of homology. All Ukrainian PPV isolates attributed to the $\mathrm{D}$ strain demonstrated at least $96 \%$ of identity to known isolates of this virus confirming the overall homogeneity of virus populations.

A level of identity of the partial $C P$ gene sequences of Ukrainian PPV isolates was in-

Table 3. Identity of Ukrainian PPV isolates with selected isolates from the GenBank by partial sequences of their $C P$ gene, \%

\begin{tabular}{l|c|c|c|c|c}
\hline \multicolumn{1}{c|}{ Isolates } & $\begin{array}{c}\text { P179 } \\
\text { (MG941019) }\end{array}$ & $\begin{array}{c}\text { EsMrP1951 } \\
\text { (MK370133) }\end{array}$ & $\begin{array}{c}\text { PEN_Plm } \\
\text { (AF354269) }\end{array}$ & $\begin{array}{c}\text { BelB9 } \\
\text { (JN596108) }\end{array}$ & $\begin{array}{c}\text { ElAmar } \\
\text { (AY847269) }\end{array}$ \\
\hline OdpeachDKd (MK209071) & 97.9 & 98 & 98 & 100 & 99 \\
\hline ChplumMSt (MK209072) & 95.7 & 94 & 93 & 94 & 94 \\
\hline OdpeachDKs (MK209073) & 98.4 & 99.5 & 99 & 99 & 95.6 \\
\hline OdplumDSt (MK209074) & 98 & 98.5 & 97.7 & 97 & 98 \\
\hline KapricotDKs (MK209075) & 97.9 & 100 & 99 & 98 & 99 \\
\hline KpeachDOk (MK209076) & 98 & 100 & 98 & 99 & 100 \\
\hline OdpeachDSt (MK209077) & 97.9 & 99 & 99 & 100 & 98 \\
\hline
\end{tabular}


dependent of either the region of sampling or the host plant. For instance, the peach isolate of PPV collected in the Odessa region (MK209071) was equally identical to both EsMrPI951 (Accession number MK370133) from Turkey and PEN Plm (Accession number AF354269) from the USA.

Expectedly, the only Ukrainian PPV isolate attributed to the $M$ strain of the virus ChplumMSt (Accession number MK209072) was less homologous to published isolates shown in Table 3 with the highest identity $(\sim 96 \%)$ to isolate P179(Accession number MG941019) which was an M strain isolate from Turkey.

Based on the partial sequence of the coat protein gene, Ukrainian isolates of plum pox virus are highly similar to known strains/isolates of PPV, suggesting the common origin or ancestor 'gene pool', exchange of genetic material between populations and/or similar evolutionary mechanisms governing virus spread and adaptation.

\section{Conclusions}

In summary, plum pox virus was found in most of the host plants in all screened regions of Ukraine, and for the first time PPV was confirmed in the Kharkiv region. Despite plum pox virus was found in many other parts of Ukraine and even in the neighboring region of Russia, it was never detected in the Kharkiv region until now. [The] Possible reasons of such ignorance include relatively small number of PPV-susceptible plants cultivated in this region commercially because of its climatic conditions as well as subsequent omittance by scientists. Using incomplete sequence of coat protein gene for the phylogenetic analysis of the Ukrainian isolates, we demonstrated prevalence of the D strain of plum pox virus in all regions, whereas the $\mathrm{M}$ strain was rarely found and infected only apricot and peach plants. Expectedly, Ukrainian PPV isolates were highly (97-100\%) similar to the majority of previously described European isolates of PPV. The data obtained may indicate their common origin and/or similar mechanisms of microevolution.

\section{REFERENCES}

1. Atanassov D. Plum pox. A new virus disease. Ann Univ Sofia Fac Agric Silvic 1932; (11):49-69.

2. Ratushnyak $L K$. Diagnostics of plums in the stone gardens. Quarantine and plant protection. 2002; (48):199-207.

3. García JA, Glasa M, Cambra M, Candresse T. Plum pox virus and sharka: a model potyvirus and a major disease. Mol Plant Pathol. 2014;15(3): 226-41.

4. Subr Z, Glasa M. Unfolding the secrets of plum pox virus: from epidemiology to genomics. Acta Virol. 2013;57(2):217-28.

5. Maejima K, Himeno M, Komatsu K, Takinami Y, Hashimoto M, Takahashi S, Yamaji Y, Oshima K, Namba $S$. Molecular epidemiology of Plum pox virus in Japan. Phytopathology. 2011;101(5): 567-74.

6. Cirilli M, Geuna F, Babini AR, Bozhkova V, Catalano L, Cavagna B, Dallot $S$, Decroocq V, Dondini L, Foschi S, Ilardi V, Liverani A, Mezzetti B, Minafra A, Pancaldi M, Pandolfini T, Pascal T, Savino VN, Scorza R, Verde I, Bassi D. Fighting Sharka in Peach: Current Limitations and Future Perspectives. Front Plant Sci. 2016;7:1290.

7. Kondratenko $P$, Udovichenko $V$. Plum pox virus (PPV) in Ukraine. Bulletin OEPP EPPO Bulletin. 2006; 36(2):217.

8. Chirkov S, Ivanov P, Sheveleva A, Kudryavtseva A, Prikhodko Y, Mitrofanova I. Occurrence and characterization of plum pox virus strain $\mathrm{D}$ isolates from 
European Russia and Crimea. Arch Virol. 2016; 161(2):425-30.

9. James D, Thompson D. Hosts and symptoms of Plum pox virus: ornamental and wild Prunus species. EPPO Bulletin. 2006; 36(2):222-224.

10. García JA, Glasa M, Cambra M, Candresse T. Plum pox virus and sharka: a model potyvirus and a major disease. Mol Plant Pathol. 2014;15(3):226-41.

11. Mavrodieva V, James D, Williams $K$, Negi S, Varga A, Mock R, Levy L. Molecular Analysis of a Plum pox virus $W$ Isolate in Plum Germplasm Hand Carried into the USA from the Ukraine Shows a Close Relationship to a Latvian Isolate. Plant Dis. 2013;97(1):44-52.

12. Prikhodko Yu N, Mazurin E S, Zhivaeva T S, Schnei$\operatorname{der} Y u A$, ,Sokolova E E. The study of plum pox virus strains. Plant protection and quarantine. 2011; (11). 29-32.

13. Norkus T, Staniulis J, Žižyte M, Melnyk M, Yusko L, Snihur H, Budzavinska I, Polischuk V. Molecular identifica-tion of Plum pox virus isolates from Lithuania and Ukraine. Zemdirbyste-Agriculture. 2008; 95(3):277-85.

14. Kyrychenko A, Shcherbatenko I, Antipov I, Hrynchuk $K$. Typing of Plum pox virus isolates in the central Ukraine. Microbiol Z. 2017; 79(3):115-24.

15. Budzanivska I, Usko L, Gospodaryk A, Melnyk M, Polischuk $V$. Epidemiology of sharka disease in Ukraine. Acta Hort. 2011; 899:57-63.

16. Cambra M, Boscia D, Myrta A, Palcovics L, Navrátil M, Barba M, Gorris MT, Capote N. Detection and characterization of Plum pox virus: serological methods. Bulletin OEPP EPPO Bulletin. 2006; 36(2). 254-261.

17. Clark MF, Adams AN. Characteristics of the microplate method of enzyme-linked immunosorbent assay for the detection of plant viruses. $J$ Gen Virol. 1977;34(3):475-83.

18. Sochor J, Babula P, Adam V, Krska B, Kizek R. Sharka: the past, the present and the future. Viruses. 2012;4(11):2853-901.

19. Wetzel T, Candresse T, Ravelonandro M, Dunez J. A polymerase chain reaction assay adapted to plum pox potyvirus detection. J Virol Methods. 1991; 33(3):355-65.
20. Olmos A, Cambra M, Dasi MA, Candresse T, Esteban $O$, Gorris MT, Asensio M. Simultaneous detection and typing of plum pox potyvirus (PPV) isolates by heminested-PCR and PCR-ELISA. J Virol Methods. 1997;68(2):127-37.

21. Subr Z, Pittnerová S, Glasa M. A simplified RTPCR-based detection of recombinant Plum pox virus isolates. Acta Virol. 2004;48(3):173-6.

22. Nemchinov L, Hadidi A. Specific oligonucleotide primers for the direct detection of plum pox potyvirus-cherry subgroup. J Virol Methods. 1998; 70(2):231-4.

\section{Генетичне різноманіття вірусу шарки сливи в Україні}

О. В. Куценко, І. Г. Будзанівська, О. В. Шевченко

Мета. Встановлення генетичного різноманіття вірусу шарки сливи (ВШС) в Україні. Методи. Імуноферментний аналіз (ІФА), полімеразна ланцюгова реакція зі зворотною транскрипцією (ЗТ-ПЛР), сиквенування ДНК та філогенетичний аналіз. Результати. Зразки були вибрані з різних регіонів України за візуальними симптомами та діагностовані за допомогою ІФА в модифікації «сендвіч». В подальшому за допомогою ЗТ-ПЛР були отримані та сиквеновані амплікони гена капсидного білку вірусу. Отриманні послідовності аналізували за допомогою філогенетичних методів. В результаті вивчено генетичне різноманіття ВШС у різних регіонах України, встановлено філогенетичні зв'язки між українськими ізолятами та проведено їх порівняльну характеристику із ізолятами з сусідніх країн. Висновки. На території України циркулюють штами M та D вірусу шарки сливи. Вперше ВШС діагностували в Харківській області. Ізоляти PPV, що циркулюють в Україні, найбільш подібні до ізолятів 3 Німеччини, Туреччини, Угорщини та Канади. Отримані результати можуть бути використані в подальшому для прогнозування поширення вірусу в різних регіонах України та сусідніх країнах, встановлення його походження та прогнозування розвитку можливих епідемій.

К л юч о в і с л о в а: вірус шарки сливи, ген капсидного білка, філогенетичний аналіз, сиквенування, генетичне різноманіття, Україна. 


\section{Генетическое разнообразие вируса шарки сливы в Украине}

О. В. Куценко, И. Г. Будзанивская, А. В. Шевченко

Цель. Изучение генетического разнообразия вируса шарки сливы (ВШС) на территории Украины. Методы. Иммуноферментный анализ (ИФА), полимеразная цепная реакция с обратной транскрипцией (ОТ-ПЦР), секвенирование ДНК и филогенетический анализ. Результаты. Образцы были отобраны из разных регионов Украины по визуальным симптомам и диагностированы с помощью ИФА в модификации «сэндвич». В дальнейшем, используя ОТ-ПЦР, были получены и секвенированы ампликоны гена капсидного белка вируса. Полученные последовательности анализировали с помощью филогенетических методов. В результате изучено генетическое разнообразие ВШС в разных регионах Украины, установлены филогенетические связи между украинскими изолятами и проведена их сравнительная характеристика с изолятами из соседних стран. Выводы. На территории Украины циркулируют штаммы М и D вируса шарки сливы. Впервые ВШС диагностировали в Харьковской области. Изоляты PPV, циркулирующие в Украине, наиболее подобные к изолятам из Германии, Турции, Венгрии и Канады. Полученные результаты могут быть использованы в дальнейшем для прогнозирования распространения вируса в различных регионах Украины и соседних странах, установления его происхождения и прогнозирования развития возможных эпидемий.

Ключе вы е слова: вирус шарки сливы, ген капсидного белка, филогенетический анализ, секвенирование, генетическое разнообразие, Украина.

Received 04.10.2019 